\title{
ANALYSIS OF FACTORS CAUSE DELAY PROJECT CONSTRUCTION BRIDGE IN THE CITY OF BANJARMASIN
}

\author{
Aulia Isramaulanan, Candra Yuliana, Hasbullah \\ Civil Engineering Department, Engineering Faculty \\ Lambung Mangkurat University, Banjarbaru, South Kalimantan, Indonesia
}

Email: aulia_isramaulana@yahoo.co.id

\begin{abstract}
With an area of $98.46 \mathrm{~km} 2$ whose territory is separated by rivers, to increase economic growth Banjarmasin City has done infrastructure development in the field of transportation of roads and bridges are quite significant. But in the process of implementation, there is often a delay in the bridge construction project. This can lead to problems within the scope of the project itself. So it is necessary to do further research to know the cause of the bridge construction project delay. This research is conducted qualitatively and quantitatively. The causative factors obtained from the literature were distributed to contractors through questionnaires to see perceptions of contractors and concessions. The data of the questionnaire were analyzed by using validity test, reliability, and descriptive statistical analysis with Pearson Moment (Bivariate Pearson) method assisted by ms. excel to get the factors causing the delay. Then the delay factors will be tested through interviews with stakeholders in the three bridge samples. Based on the results of data processing analysis, it can be concluded that the factors that greatly affect the bridge construction project delays are analyzed by descriptive analysis of material arrival delay, material arrival delay, damage due to negligence of work, and work that does not comply with operational standards
\end{abstract}

Keywords : Delays, questionnaires, Pearson Moments (Bivariate Pearson), interviews, bridges

\section{INTRODUCTION}

The city of Banjarmasin has been widely known by the nickname 1000 River City. This nickname refers to the number of rivers that divide the mainland of Banjarmasin City. This unique natural configuration when viewed from the air just shows the area of Banjarmasin city like a collection of small islands split by the river.

Many people think that the unique configuration and characteristic of Banjarmasin city that many flow by river with various sizes, is a big capital for long term development and if the commitment of governance and exploitation process can be done well and correctly, it is possible to make Banjarmasin city become a a unique and beautiful city.

With an area of $98.46 \mathrm{~km} 2$ of which the area is separated by rivers, to increase economic growth Banjarmasin City has done the development of infrastructure in the field of transportation of roads and bridges are quite significant with the details of APBD as follows in Table 1.

Table 1, shows the use of APBD budget for the last three years of Banjarmasin city. Roads and bridges have a large share in the use of budget over the past three years. These data show how important the construction of transportation (roads and bridges) in the city of Banjarmasin is cleaved by many rivers.

But in the process of implementation, there is often a delay in the bridge construction project. This can lead to problems within the scope of the project itself, one of which is the occurrence of cost swelling that also affects the quality of the work. Delays result in losses for project-related parties, especially contractors as executors who have to spend more to pursue the late work. Therefore more attention is required in analyzing what factors are responsible for delays in bridge construction projects. 
Table 1. APBD funds Dinas Bina Marga Banjarmasin

\begin{tabular}{|c|c|c|c|}
\hline Fiscal year & APBD & Fiscal & Percentage \\
\hline \multirow[t]{6}{*}{2015} & Secretariat & Rp $2,980,750,000$ & $2.46 \%$ \\
\hline & Program & $\operatorname{Rp} \quad 4,046,000,000$ & $3.34 \%$ \\
\hline & Road & Rp $64,976,000,000$ & $53.76 \%$ \\
\hline & Bridge & $\operatorname{Rp} 29,661,610,000$ & $24.54 \%$ \\
\hline & Public Street Lighting & Rp $19,200,000,000$ & $15.88 \%$ \\
\hline & Total Funds & Rp $120,846,410,000$ & \\
\hline \multirow[t]{6}{*}{2016} & Secretariat & $\mathrm{Rp} \quad 2,633,658,000$ & $1.38 \%$ \\
\hline & Program & $3,930,000,000$ & $1.90 \%$ \\
\hline & Road & Rp $111,545,500,000$ & $58.50 \%$ \\
\hline & Bridge & Rp $51,294,110,000$ & $26.90 \%$ \\
\hline & Public Street Lighting & Rp $21,250,000,000$ & $11.14 \%$ \\
\hline & Total Funds & Rp190,653,268,000 & \\
\hline \multirow[t]{8}{*}{2017} & Secretariat & Rp $5,650,207,000$ & $3.11 \%$ \\
\hline & Public Street Lighting & $\operatorname{Rp} 70,554,092,000$ & $38.84 \%$ \\
\hline & Bridge & Rp $20,498,000,000$ & $11.28 \%$ \\
\hline & River & $\operatorname{Rp} 17,978,503,000$ & $9.89 \%$ \\
\hline & Drainage & Rp $8,830,000,000$ & $4.86 \%$ \\
\hline & Contractor services & Rp $55,563,000,000$ & $30.59 \%$ \\
\hline & Spatial & $\operatorname{Rp} \quad 2,538,038,000$ & $1.39 \%$ \\
\hline & Total Funds & $\operatorname{Rp} 181,611,840,000$ & \\
\hline
\end{tabular}

\section{MATERIALS AND METHODS}

The purpose of this study is to determine the factors causing delays in the city of Banjarmasin by distributing questionnaires and interviews to the parties related to bridge construction projects in the city of Banjarmasin which later expected useful as a reference for the contractor to avoid delays in the implementation of bridge construction project and become a reference in subsequent research.

A project is declared completed when the time and quality of work are in accordance with the initial contract, to achieve this required good managerial for the executor of the bridge construction project. If a time of the work process is delayed, the implementer can take strategic steps to overcome this so that the project can be completed on time and on quality.

In this research, starting with the physical delay of work that occurred in some bridge construction project. Then followed by a study of literature related topics that will be discussed is about the bridge construction project delay, then conducted secondary data collection needed to analyze and discuss so that can be drawn conclusions.

Surveys are a systematic method of collecting data based on a sample to obtain information from similar populations. The main purpose of the survey is not to determine a specific case, but to obtain the main characteristics of the targeted population at a given time.
Implementation of this research is done in accordance with the method of questionnaire research and interviews to the parties related to the project, the research stages starting from data collection to the analysis used to process data and statistical calculations, data collection research conducted by spreading questionnaires whose variables are determined. Then the results of the results of the calculation of the questionnaire data analysis will know what factors are the cause of the delay and will be tested through interviews with the parties related to the construction project of the bridge

\section{RESULTS AND DISCUSSION}

From the analysis results obtained correlation value between the score of items with a total score. The analysis is calculated using Ms. Excel first to get the item score, the total score and the correlation value of the item score and the total score. This value is then appealed to $r$ table value, $r$ table is searched for significance 0.05 with 2 side test and amount of data $(n)=30$.

The sample for the questionnaire test of 30 respondents who have been or are handling the bridge project with $5 \%$ significance from here obtained value $\mathrm{df}=\mathrm{n}-2, \mathrm{df}=30-2=28$. We see from table $r$ moment product at $5 \%$ significance, $r$ table $=0.361$, then compare the value of $r$ table with $r$ calculation result. If in $r$ arithmetic $>r$ table, then the statement is "Valid". Conversely, if $r$ count $<r$ table, then the statement is "Invalid". 
Aulia Isramaulanan, Candra Yuliana, Hasbullah: Analysis of Factors Cause Delay Project ...

Table 2. Item Instrument Validation (Impact on Delay)

\begin{tabular}{|c|c|c|c|c|}
\hline Code & Variable & $\begin{array}{c}\text { Value } r \\
\text { ( } r \text { count }) \\
\end{array}$ & $\begin{array}{c}\text { Value } \\
(r \text { table }) \\
\end{array}$ & Conclusion \\
\hline f1 & Lack of training & 0,293801457 & 0.361 & Invalid \\
\hline $\mathrm{f} 2$ & Personnel who work are not in accordance field & $-0,332307072$ & 0.361 & Invalid \\
\hline f3 & Lack of work experience & $-0,112530209$ & 0.361 & Invalid \\
\hline $\mathrm{f} 4$ & Lack of skilled labor & $-0,253111406$ & 0.361 & Invalid \\
\hline f5 & Human error in the execution of work & 0,279477177 & 0.361 & Invalid \\
\hline f6 & Schedule is not realistic & 0,508011833 & 0.361 & Valid \\
\hline $\mathrm{f7}$ & Poor time management & $-0,119191762$ & 0.361 & Invalid \\
\hline f8 & Work plans change & 0,424436202 & 0.361 & Valid \\
\hline f9 & Short project implementation period & 0,338703787 & 0.361 & Invalid \\
\hline f10 & Implementation methods are less precise & $-0,475247253$ & 0.361 & Invalid \\
\hline f11 & Coordination is less clear & 0,282291067 & 0.361 & Invalid \\
\hline f12 & Coordination with implementation is not appropriate & 0,552280183 & 0.361 & Valid \\
\hline f13 & Misunderstanding in receiving information & 0,312209696 & 0.361 & Invalid \\
\hline f14 & Lack of communication and coordination in the field & 0,427200169 & 0.361 & Valid \\
\hline f15 & Submission of incomplete information & 0,224090234 & 0.361 & Invalid \\
\hline f16 & Low capacity and productivity of equipment & $-0,092845419$ & 0.361 & Invalid \\
\hline f17 & Lack of material & 0,474030231 & 0.361 & Valid \\
\hline f18 & Material arrive delay & $-0,143269424$ & 0.361 & Invalid \\
\hline f19 & Material quality is not appropriate & 0,146167026 & 0.361 & Invalid \\
\hline $\mathrm{f} 20$ & Inefficient use of tools & 0,280799706 & 0.361 & Invalid \\
\hline $\mathrm{f} 21$ & Unexpected weather & 0,424223481 & 0.361 & Valid \\
\hline $\mathrm{f} 22$ & Damage due to work negligence & 0,236818779 & 0.361 & Invalid \\
\hline $\mathrm{f} 23$ & Accident at work occurred & 0,028723205 & 0.361 & Invalid \\
\hline $\mathrm{f} 24$ & The existence of unexpected constraints on the work & 0,218035237 & 0.361 & Invalid \\
\hline $\mathrm{f} 25$ & There was a work error & 0,533539658 & 0.361 & Valid \\
\hline $\mathrm{f} 26$ & $\begin{array}{l}\text { The physical condition of the environment is not } \\
\text { supported }\end{array}$ & $-0,279965609$ & 0.361 & Invalid \\
\hline $\mathrm{f} 27$ & Licensing is slow & 0,346060199 & 0.361 & Invalid \\
\hline $\mathrm{f} 28$ & Lack of initial capital & 0,341135030 & 0.361 & Invalid \\
\hline $\mathrm{f} 29$ & Cost estimation error & 0,356775341 & 0.361 & Invalid \\
\hline $\mathrm{f} 30$ & Late owner payment to contractor & $-0,377394740$ & 0.361 & Invalid \\
\hline $\mathrm{f} 31$ & Errors in financial administration & 0,118505330 & 0.361 & Invalid \\
\hline f32 & Incompatibility of work agreement & 0,305597830 & 0.361 & Invalid \\
\hline f33 & Employee wage delays & $-0,051397782$ & 0.361 & Invalid \\
\hline f34 & The results of the work did not reach the quality set & $-0,290912435$ & 0.361 & Invalid \\
\hline $\mathrm{f} 35$ & Error in the sequence of job steps & 0,189308192 & 0.361 & Invalid \\
\hline $\mathrm{f} 36$ & Jobs that do not comply with operational standards & 0,232131637 & 0.361 & Invalid \\
\hline
\end{tabular}


Aulia Isramaulanan, Candra Yuliana, Hasbullah: Analysis of Factors Cause Delay Project ...

Table 3. Item Instrument Validation (Impact on Quality of Work Quality)

\begin{tabular}{|c|c|c|c|c|}
\hline Code & Variable & $\begin{array}{l}\text { Value } r \\
(r \text { count }) \\
\end{array}$ & $\begin{array}{c}\text { Value } \\
(\mathrm{r} \text { table }) \\
\end{array}$ & Conclusion \\
\hline $\mathrm{f1}$ & Lack of training & 0.145911 & 0.361 & Invalid \\
\hline f2 & Personnel who work are not in accordance field & 0.252423 & 0.361 & Invalid \\
\hline f3 & Lack of work experience & 0.352889 & 0.361 & Invalid \\
\hline f4 & Lack of skilled labor & 0.109758 & 0.361 & Invalid \\
\hline f5 & Human error in the execution of work & 0.343289 & 0.361 & Invalid \\
\hline f6 & Schedule is not realistic & 0.077583 & 0.361 & Invalid \\
\hline f7 & Poor time management & 0.297266 & 0.361 & Invalid \\
\hline f8 & Work plans change & 0.555698 & 0.361 & Valid \\
\hline f9 & Short project implementation period & 0.341355 & 0.361 & Invalid \\
\hline $\mathrm{f} 10$ & Implementation methods are less precise & 0.203677 & 0.361 & Invalid \\
\hline$f 11$ & Coordination is less clear & 0.574652 & 0.361 & Valid \\
\hline$f 12$ & Coordination with implementation is not appropriate & 0.304949 & 0.361 & Invalid \\
\hline$f 13$ & Misunderstanding in receiving information & 0.208115 & 0.361 & Invalid \\
\hline$f 14$ & Lack of communication and coordination in the field & 0.278034 & 0.361 & Invalid \\
\hline$f 15$ & Submission of incomplete information & -0.018770 & 0.361 & Invalid \\
\hline f16 & Low capacity and productivity of equipment & -0.159989 & 0.361 & Invalid \\
\hline $\mathrm{f} 17$ & Lack of material & 0.304901 & 0.361 & Invalid \\
\hline$f 18$ & Material arrive delay & 0.172644 & 0.361 & Invalid \\
\hline$f 19$ & Material quality is not appropriate & 0.372044 & 0.361 & Valid \\
\hline $\mathrm{f} 20$ & Inefficient use of tools & 0.049389 & 0.361 & Invalid \\
\hline $\mathrm{f} 21$ & Unexpected weather & 0.028717 & 0.361 & Invalid \\
\hline f22 & Damage due to work negligence & 0.394293 & 0.361 & Valid \\
\hline f23 & Accident at work occurred & 0.316865 & 0.361 & Invalid \\
\hline$f 24$ & The existence of unexpected constraints on the work & 0.296790 & 0.361 & Invalid \\
\hline$f 25$ & There was a work error & 0.542379 & 0.361 & Valid \\
\hline $\mathrm{f} 26$ & $\begin{array}{l}\text { The physical condition of the environment is not } \\
\text { supported }\end{array}$ & -0.309161 & 0.361 & Invalid \\
\hline $\mathrm{f} 27$ & Licensing is slow & 0.235397 & 0.361 & Invalid \\
\hline $\mathrm{f} 28$ & Lack of initial capital & -0.107563 & 0.361 & Invalid \\
\hline f29 & Cost estimation error & 0.207844 & 0.361 & Invalid \\
\hline $\mathrm{f} 30$ & Late owner payment to contractor & 0.141998 & 0.361 & Invalid \\
\hline $\mathrm{f} 31$ & Errors in financial administration & 0.324388 & 0.361 & Invalid \\
\hline f32 & Incompatibility of work agreement & 0.101518 & 0.361 & Invalid \\
\hline f33 & Employee wage delays & -0.049237 & 0.361 & Invalid \\
\hline f34 & The results of the work did not reach the quality set & 0.216376 & 0.361 & Invalid \\
\hline f35 & Error in the sequence of job steps & 0.171474 & 0.361 & Invalid \\
\hline f36 & Jobs that do not comply with operational standards & 0.169731 & 0.361 & Invalid \\
\hline
\end{tabular}

Based on correlation analysis result obtained correlation value for:

1. Invalid items (project delays) items $\mathrm{f} 1, \mathrm{f} 2, \mathrm{f} 4$, $f 5, f 7, f 9, f 10, f 11, f 13, f 15, f 16, f 18, f 19, f 20$, f22, f23, f24, f26, f27, f28, f30, f31, f32, f33, $\mathrm{f} 34, \mathrm{f} 35$, dan $\mathrm{f} 36$.

2. Invalid items (impact on quality) items $\mathrm{f} 1, \mathrm{f} 2$, $\mathrm{f3}, \mathrm{f} 4, \mathrm{f} 5, \mathrm{f} 6, \mathrm{f} 7, \mathrm{f9}, \mathrm{f10}, \mathrm{f12}, \mathrm{f13}, \mathrm{f} 14, \mathrm{f} 15, \mathrm{f} 16$, $\mathrm{f} 17, \mathrm{f} 18, \mathrm{f} 20, \mathrm{f} 21, \mathrm{f} 23, \mathrm{f} 24, \mathrm{f} 26, \mathrm{f} 27, \mathrm{f} 28, \mathrm{f} 29$, f30, f31, f32, f33, f34, f35, dan f36.

Because the value of $r$ count is less than 0.361 ( $r$ table), it can be concluded that the items are not correlated significantly with the total score and declared invalid, so it must be issued. While on other items value more than 0.361 and can be concluded that the instrument is valid.

The values for reliability testing come from valid item scores. Invalid items are not involved in reliability testing. as follows:

Categories of reliability coefficients are

- $0.80-1.00$ : reliability is very high

- $\quad 0.60-0.80:$ High reliability

- $\quad 0.40-0.60$ : moderate reliability

- 0.20 - 0.40: Low reliability

- $-1.00-0.20$ : very low reliability (not reliable)

Reliability testing using Pearson method, used to assess whether the data of the questionnaire can be trusted or not.

From Excel calculations for questionnaire reliability:

- Impact on the delay obtained (R) of 0.58 .

- Impact on quality quality obtained (R) of 0.63.

Then proceed with the next test, that is by entering the correlation value into the Spearman Brown formula:

1. $R=2 r / 2+r=2(0,58) / 2+0,58=0,45$ 
2. $R=2 r / 2+r=2(0.63) / 2+0.63=0.48$

Thus instruments for:

1. Impacts on delays have moderate reliability due to $0.45>0.40$ and meet criteria due to $0.45>r$ table $(0.361)$. So this comparison shows significant results, or in other words reliability of the instrument can be trusted.
2. Impact on the quality of work has moderate reliability due to $0.48>0.40$ and meets the criteria due to $0.48>r$ table $(0.361)$. So this comparison shows significant results, or in other words reliability of the instrument can be trusted.

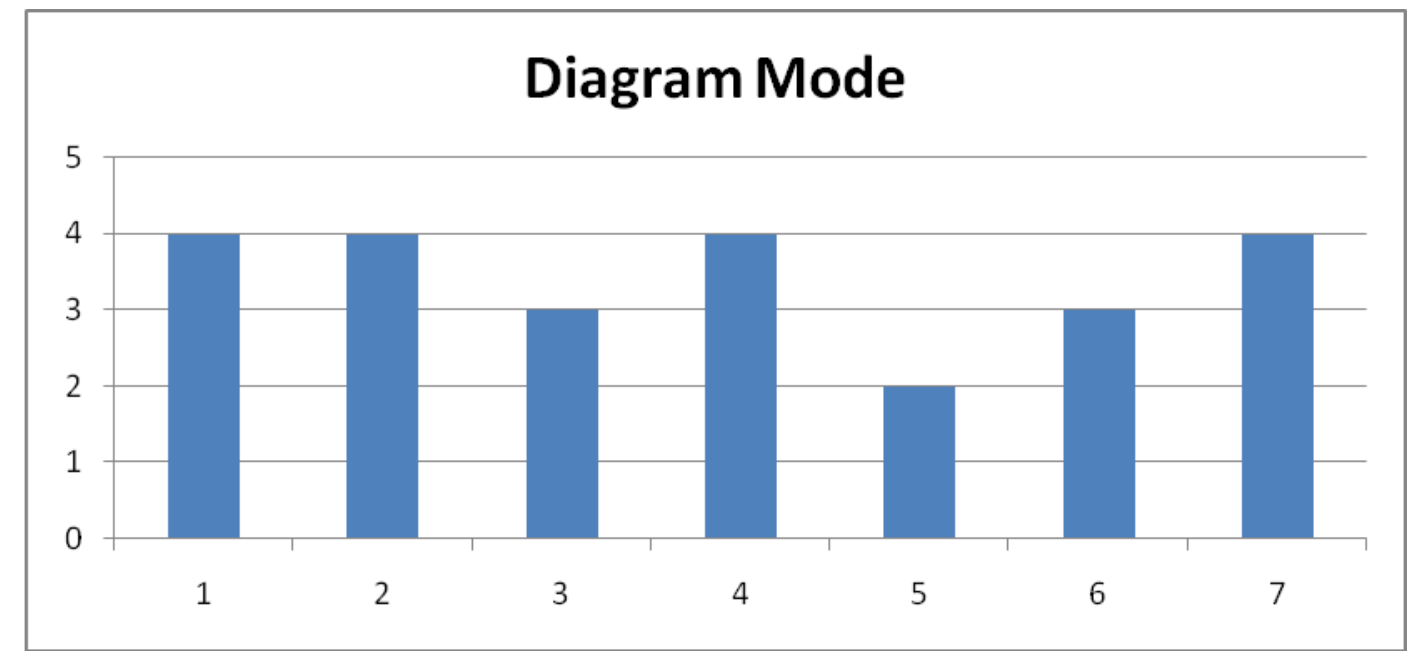

Picture 1. Diagram of factor values for project delays

The diagram above shows the most - The work plan is fickle (f8) common value (mode) in the questionnaire: Highest mode value:

- Schedule is not Realistic (f6)

- Lack of communication and coordination in the field (f14)

- There was a work error (f25)

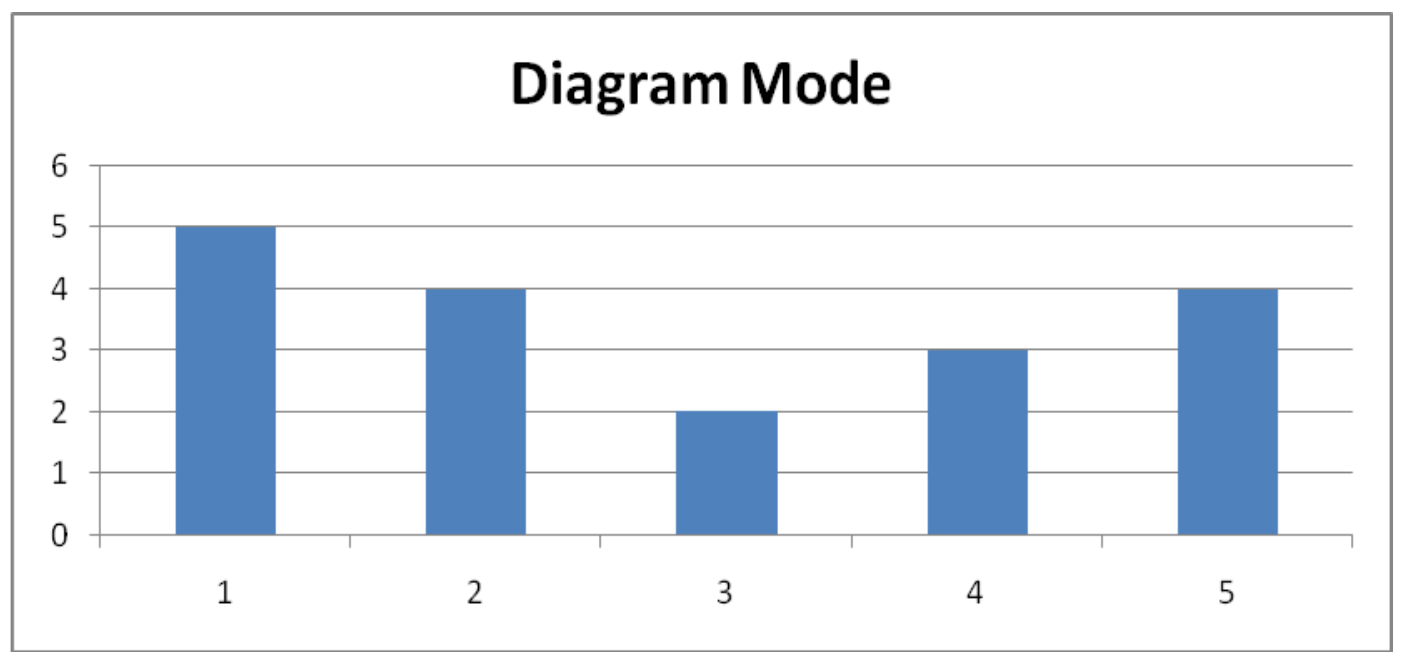

Picture 2. Diagram of Factor Values Against Working Quality

The diagram above shows the most common value (mode) in the questionnaire:

Highest mode value:

- The work plan is fickle (f8)

- Coordination is less clear (f11)

- There was a work error (f25)

\section{Comparison of Questionnaire and Interview Results}

The variable of valid questionnaire result will be compared with the result of interview to the related parties of the three bridge project samples. The factors that cause the delay of 
the results of the distribution of questionnaires and interview results are listed in Table 4.

Table 4. Comparison of Questionnaire Results and Interview Result of Bridge Samples (Delays)

\begin{tabular}{|c|c|}
\hline Questionnaire results (valid item) & Interview result \\
\hline Schedule is not realistic & Coordianation is less clear \\
\hline Work plans change & Lack of communcation and coordination in the field \\
\hline $\begin{array}{l}\text { Coordination with implementaion is not } \\
\text { appropriate }\end{array}$ & $\begin{array}{l}\text { Material arrival delay } \\
\text { Unexpected weather }\end{array}$ \\
\hline $\begin{array}{l}\text { Lack of communcation and coordination in the } \\
\text { field }\end{array}$ & $\begin{array}{l}\text { The exixtence of unexpected constraints on the work } \\
\text { process }\end{array}$ \\
\hline Lack of material & Licensing is low \\
\hline Unexpected weather & \\
\hline There was a work error & \\
\hline
\end{tabular}

When compared between the results of the questionnaire distribution test and the interview results differ and not all the same, this is possible because based on the experience of each company that handles different bridges. The delay factors of the questionnaire distribution were broader in sampling, but the authors could not ascertain who filled the questionnaire. Interviews were drawn from three bridge samples, but the authors made sure that the resource person was the right person or person who witnessed the on-the-job process in the field and became the source in knowing the delay factors that occurred in the work process.

\section{Influence of Delays on Quality}

Based on the results of interviews with related parties on the above three bridge project samples, the delay of the work faced by the contractor does not affect the quality of the quality test, because the work in the field is done in accordance with the work procedures or comply with the SNI standards so the delay is considered not to affect the quality of the test quality. But it is more influential on costs because the contractor has to spend more for the overtime wages of workers in the field. However, the source persons from related parties bridge samples justify some of the factors that often cause low quality in the work process, among others:

Table 5. Comparison of Questionnaire Results and Interview Results of Bridge Samples (Quality of Quality)

\begin{tabular}{ll}
\hline \multicolumn{1}{c}{ Questionnaire results (valid item) } & \multicolumn{1}{c}{ Interview result } \\
\hline Work plans change & Coordianation is less clear \\
Coordination is less clear & Material quality is not appropriate \\
Material quality is not appropriate & There was a work error \\
Damage due to work negligence & The physical condition of the environment is not \\
Accident at work occurred & supportive \\
& Error in the sequence of jobs steps \\
& Jobs that do not comply with operational standards \\
\hline
\end{tabular}

\section{CONCLUSION}

Based on the results of the analysis of the questionnaire and interview results, it can be concluded that:

a. The factors causing the delay in bridge construction project in Banjarmasin are Unrealistic schedule; The work plan is fickle; Unclear coordination with implementation; Lack of communication and coordination in the field; Shortage and delay of material arrival; Unexpected weather; There was a work error and Licensing is slow

b. Factors that are the cause of the quality of bridge construction project in Banjarmasin are Fluctuating work plans and work sequence errors; Coordination is less clear; Material quality is not appropriate; Damage due to work negligence; There was a work error; Lack of material; The physical condition of the environment does not support and Jobs that do not comply with operational standards 
Aulia Isramaulanan, Candra Yuliana, Hasbullah: Analysis of Factors Cause Delay Project ...

\section{REFERENCES}

Aksan (2005). Quality Control. Retrieved on May $\quad 9 \quad 2017 \quad$ from https://www.scribd.com/doc/7959757/ TRUTION-MUTU

Cahyanti (2005). Implementation of Concrete Works for Roads and Bridges retrieved on May 112017 from http://www.academia.edu/5858474/Bu ilding_Pekerjaan_Beton_Untuk_Jalan dan Jembatan /

Furwanti (2006). Manajemen Quality. Retrieved on May 9, 2017 from https://www.scribd.com/doc/36435927 /Module-Management-Mutu

Puspitasari, N. (2010). Analysis of Construction Project Delay Factor. S1 Civil Engineering. University of Lambung Mangkurat. Banjarbaru.

Riduwan (2003). Statistics Basic. Alfabeta.Bandung.

Widiani, W.I. (2017). Rescheduling of D.A.K Jembatan Sudirman II Construction Work. S1 Civil Engineering Universitas Lambung Mangkurat. Banjarbaru.

Yuliana, C. (2013). Factor Analysis Causes Late Delays in the Implementation of Bridge Construction Project. Technical Info 14 (2). 